EDITORIAL

\title{
NOVOS DESENVOLVIMENTOS TEÓRICOS EM CONTABILIDADE
}

Entre os estudiosos, parece haver consenso de que a Contabilidade ainda não dispõe de um corpo teórico devidamente consolidado em função do qual seja possível formular explicações e predições para as suas práticas. De igual forma, considera-se que essa ausência de paradigmas em torno dos quais a comunidade científica possa investigar fenômenos de natureza contábil é conseqüência do próprio processo evolutivo por que passa a contabilidade. Parte-se da idéia de que as grandes transformações que cercam o ambiente econômico tendem a exercer impactos significativos sobre as práticas contábeis e, conseqüentemente, sobre o poder explicativo e preditivo de certas ferramentas teóricas.

De fato, alguns desafios que têm recaído sobre a contabilidade de forma mais pronunciada nos últimos anos, tais como mensuração de recursos intangíveis, evidenciações de caráter social, reformulação de normas, prevenção de escândalos corporativos e quantificação de passivos ambientais acabam imprimindo uma nova feição à prática contábil. Nesse contexto, é de se esperar que haja um incremento na demanda por teorias que possam explicar as práticas contábeis e o próprio comportamento dos usuários da contabilidade.

Outro fator que tem estimulado novos desenvolvimentos teóricos em contabilidade é o crescente número de investigações empíricas que se realizam em torno das políticas de evidenciação contábil. Ao contrário do que se verificava até meados do século passado, nas últimas décadas a pesquisa em contabilidade tem sido orientada predominantemente para fornecer explicações a respeito de determinados fenômenos, como por exemplo o comportamento dos usuários das informações contábeis. Em outras palavras, poderíamos dizer que a pesquisa em contabilidade vem se distanciando cada vez mais de posturas meramente prescritivas e aderindo a métodos de investigação mais consentâneos com o verdadeiro espírito da ciência. Como se pode deduzir, essa mudança de paradigma acaba reforçando a demanda por teorias que contribuam para explicar e predizer as práticas contábeis. Uma das que ganhou mais notoriedade nos últimos anos, pelo menos nos ambientes acadêmicos de maior prestígio, é a Teoria Positiva da Contabilidade.

Associado a isso, a visão de que a contabilidade não é uma simples ferramenta de apoio a decisões de caráter econômico também veio contribuir para que se realizassem investigações a partir de novas abordagens teóricas. Por exemplo, a idéia de que os sistemas contábeis são produto das práticas, crenças, valores e modelos que predominam em determinada sociedade abriu espaço para a realização de estudos baseados na teoria institucional. De igual forma, a noção de que a contabilidade é utilizada para imprimir traços de racionalidade às organizações e de que ela afeta o mundo em que vivemos, as estruturas sociais, as relações entre o Estado e os cidadãos, as relações entre empregado e patrão, vem estimulando o uso de teorias derivadas da sociologia em pesquisas contábeis.

Como se observa, as diferentes visões do papel que a contabilidade exerce na sociedade têm motivado a realização de pesquisas sob diversas perspectivas teóricas. Mais recentemente, a percepção de que as organizações precisam ganhar, manter ou recuperar legitimidade no ambiente em que operam para garantir o cumprimento de seus objetivos vem ensejando a realização de pesquisas sob o enfoque da teoria da legitimidade. Em geral, considera-se que esse arranjo teórico pode ser útil para explicar, por exemplo, porque determinadas empresas tendem a 
investir mais do que outras em evidenciações de caráter social independentemente de exigências legais.

Finalmente, assumindo a Contabilidade como um processo de identificação, mensuração e comunicação, pesquisadores vêm explorando conceitos da Semiótica para avaliar o efeito das práticas contábeis e identificar problemas a elas associados. Isto porque a Semiótica é geralmente definida como o ramo do conhecimento que se dedica ao estudo de todas as linguagens e, coincidentemente, a contabilidade tem sido reconhecida como um tipo de linguagem. Tanto é assim que, freqüentemente, a literatura faz referência ao valor sintático, semântico e pragmático das informações contábeis. Por isso, a exemplo do que se verifica em outras áreas do conhecimento, como Direito, Medicina e Arquitetura, cresce o entendimento de que a pesquisa contábil pode se beneficiar de recursos fornecidos pela Semiótica e pela Teoria da Comunicação.

Ante o exposto, conclui-se que a crescente demanda por teorias em Contabilidade não deve ser interpretada como um problema para esse ramo do conhecimento e muito menos como uma fragilidade a ele associada. Pelo contrário, como teorias são abstrações da realidade, não se pode esperar que elas forneçam explicações absolutamente completas para certos comportamentos ou descrições perfeitas de alguns fenômenos. Nesse caso, é perfeitamente natural e até desejável que se considere a possibilidade de realizar investigações sob o enfoque de teorias alternativas. Entendemos que esse é um caminho natural e necessário para a evolução de qualquer ramo do conhecimento humano, inclusive a Contabilidade, é claro.

José Maria Dias Filho Professor Doutor da Faculdade de Ciências Contábeis da UFBA 